\begin{tabular}{|c|c|c|}
\hline IDUNAS & $\begin{array}{c}\text { NATURAL \& APPLIED SCIENCES } \\
\text { JOURNAL }\end{array}$ & $\begin{array}{c}2019 \\
\text { Vol. } 2 \\
\text { No. 2 }\end{array}$ \\
\hline
\end{tabular}

\title{
Antibacterial activities of Some Mixed Isoniazid-Ibuprofen Metal Complexes: Chelation and Characterization
}

\author{
Research Article
}

\author{
Mercy O. Bamigboye *1 (iD), Ikechukwu P. Ejidike2 ${ }^{D}$, R. N. Ahmed3 \\ IDepartment of Industrial Chemistry, University of Ilorin, Ilorin, Nigeria \\ 2Department of Chemical Sciences, Faculty of Science and Science Education, Anchor University, Lagos, Nigeria \\ 3 Department of Microbiology, University of Ilorin, Ilorin, Nigeria \\ Author E-mail: \\ seymercyx@yahoo.com \\ Tel: +2347033328218 \\ *Correspondence to: M. O. Bamigboye, Department of Industrial Chemistry, University of Ilorin, Ilorin, \\ Nigeria \\ DOI: 10.38061/idunas.631229
}

Received: October 09, 2019; Accepted: December 31, 2019

\section{Abstract}

The input of metallo-pharmaceutical to biomedical research is of high remarkable effect in drug design either as therapeutic, diagnostic or MRI imaging agents to mention few. Ranges of $\mathrm{d}$ - orbital transition metals: $\mathrm{Cu}(\mathrm{II}), \mathrm{Zn}(\mathrm{II}), \mathrm{Mn}(\mathrm{II}), \mathrm{Ni}(\mathrm{II})$, and $\mathrm{Cd}(\mathrm{II})$ complexes bearing Isoniazid-Ibuprofen mixed ligands have been synthesized. The prepared complexes were characterized by using microanalytical, infrared spectroscopy and CHN elemental analysis. FT-IR spectroscopic data showed that the ligands coordinate to the metal ion via the oxygen and nitrogen donor atoms from Isoniazid and oxygen of the carboxylic group and oxygen of the hydroxyl group of Ibuprofen. The elemental analysis measurement supports an octahedral geometry complexes proposed in line with the electronic structures of the metal ions. Comparative antibacterial study of the synthesized metal complexes and their parent ligands against Escherichia Coli, Staphylococcus aureus, and Pseudomonas aeruginosa microorganisms were carried out. $\left[\mathrm{Ni}(\mathrm{ISO})(\mathrm{IBR}) \mathrm{Cl}_{2}\right]$ and $\left[\mathrm{Co}(\mathrm{ISO})(\mathrm{IBR}) \mathrm{Cl}_{2}\right]$ exhibited the highest antibacterial activities than other complexes, however, the metal complex activities were found higher than the free ligands.

Keywords: spectroscopic, isoniazid, ligands, antibacterial, metal Complex

\section{INTRODUCTION}

The use of metal complexes and their applications in medicine have continued to increase. Metal complexes have found application as medicinal agents in the treatment of various diseases. Recently, platinum (II) complexes have been screened as antitumor drugs, while silver and gold complexes have been used as antibacterial and antiarthritic agents with gold compounds (auranofin, solganol and miochrysine) found to be very important in treatment of arthritis (Naglah et al., 2015). 
Tuberculosis (TB) has been known to be a disease that produces millions of deaths annually, being the leading cause of mortality in developing countries. The number of persons infected with tuberculosis is also growing in developing countries, especially in persons infected with the human immunodeficiency virus (HIV) (Maria et al.,2013; Arounaguiri et al., 2000; Adadey and Sarfo, 2016; Poggi et al., 2013).

Isoniazid has been known to be an antimycobacterial drug effective in the prevention and treatment of tuberculosis (Mukherjee, 2000; Diana et al., 2012). It is also of considerable interest due to its ability to coordinate with metals via the heterocyclic nitrogen atom of the pyridine ring and/or the carbonyl oxygen and nitrogen atoms of the hydrazide group (Obaleye et al., 2011). Ibuprofen ( $\alpha, \alpha-m e t h y l-4-(2-$ methylpropyl) benzenaceticacid) is known to be an important non-steroidal anti-inflammatory drug (NSAID). It has finds application in the treatment of inflammatory and painful rheumatic and non-rheumatic diseases (Amolegbe et al., 2012). The carboxylate group in its structure makes it possible for metal-ligand interactions.
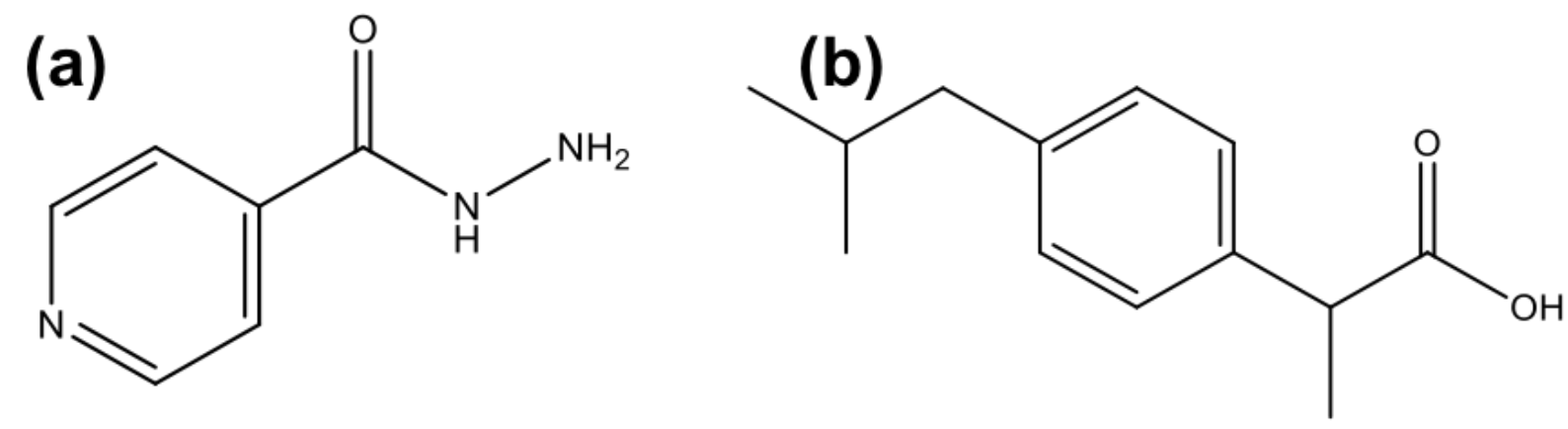

Fig. 1: Structure of (a) Isoniazid; (b) Ibuprofen

An increase in drug-resistant microbial strains of the disease (MDR-TB) has been of alarming rate making it difficult for the control of the disease effectively. In addition to this, drug-drug interactions have been observed between TB drugs and anti-HIV treatments and other medications used in treatment of chronic disease such as diabetics (Obaleye et al., 2011).

Research into synthesis and application of drug-metal complexes for the purpose of new drug synthesis is of great interest in inorganic, pharmaceutical and medicinal chemistry. Isoniazid is a front-line drug used in the treatment of Tuberculosis. "The major route of isoniazid resistance relies on KatG enzyme disruption, which does not promote an electron transfer reaction' (Chaudhary et al., 2005). Schiff bases of metal complexes of nitrogen and oxygen donor is of great interest due to different biological activities of pharmacological, antitumour, fungicide, bactericide, anti-inflammatory, and antiviral activities (Prasad and Agarwal, 2007; Mewis and Archibald, 2010). Metal complexes have been greatly known as medicinal agents in the treatment of diseases. There are some platinum (II) complexes used clinically as antitumor drugs (Diana et al., 2012). It has been observed that Ibuprofen -copper and zinc complexes are used as preservative solutions which penetrate wood. With the absence of the ammonia from the wood, the complexes are retained in the wood providing a long-lasting preservative (Tella and Obaleye, 2010). 


\section{EXPERIMENTAL SECTION}

Isoniazid and Ibuprofen were purchased from Sigma Aldrich. All the reagents and chemicals used for this research work were of analytical grade. They were purified by standard procedure. The IR spectra of the complexes were carried out and reported using FT-IR Spectrophotometer at Redeemer University, Nigeria. The elemental analysis was carried out and reported at Medac Limited, Brunel Science, Egham, United Kingdom for the determination of percentage chemical elements $(\mathrm{CHN})$ present in the complexes.

\subsection{Synthesis of the complexes [M(IBR)(ISO)Cl2]}

The procedure described by (Tella and Obaleye, 2010 )was followed with little modification in the synthesis of these complexes. $0.14 \mathrm{~g}(1 \mathrm{mmol})$ of Isoniazid in $20 \mathrm{ml}$ of methanol and $0.21 \mathrm{~g}(1 \mathrm{mmol})$ of Ibuprofen in $20 \mathrm{ml}$ of ethanol were mixed together with the chloride salts of the metals $\left(\mathrm{M}=\mathrm{Cu}_{2+}, \mathrm{Zn}_{2+}, \mathrm{Mn}_{2+}, \mathrm{Ni}_{2+}, \mathrm{Cd}_{2+}\right)$ dissolved in the suitable solvents. The mixture was refluxed for three hours at a determined temperature and allowed to cool at room temperature. A precipitate was obtained, filtered and washed with the mixed solvent used to remove any unreacted substances. It was dried in a desiccator and stored in a sample bottle for further analysis.

\subsection{Antimicrobial screening}

Nutrient broth was used in this study to activate the growth of the selected organisms. It was prepared by weighing $4 \mathrm{~g}$ of the Nutrient broth in $250 \mathrm{ml}$ of the conical flask containing distilled water to dissolve. The conical flask was plugged with a well fitted cotton wool and wrapped with an aluminum foil. It was then sterilized in an autoclave at $121{ }^{\circ} \mathrm{C}$ for fifteen minutes. It was transferred into petri- dish and allowed to cool. Hole borer was used to form a hole at the center of the solidified agar. The selected organisms were introduced at the hole and incubated at $37 \mathrm{o}$ C for twenty-four hours. The plates were checked for possible zones of inhibition (Tella and Obaleye, 2013). 


\subsection{Determination of Minimum Inhibitory Concentration (MIC)}

Procedure followed by (Collins et al., 1995) was adopted. The free ligands and their complexes were prepared at concentration of 20 and $40 \mathrm{mg} / \mathrm{ml}$ and were transferred into different test tube. The test tube was inoculated with some selected isolated organisms such as Escherichia Coli, Staphylococcus aureus and Pseudomonas aeruginosa. They were diluted to obtain a final concentration of about hundred cells per ml. The prepared test tubes were then incubated at $37{ }^{\circ} \mathrm{C}$ for twenty hours. It was observed that the complexes that has the least concentration inhibited the growth of the isolated organisms in broth cultured.

\subsection{Determination of Minimum Bactericidal Concentration (MBC)}

After the isolated organisms has been cultured separately in the nutrient broth of different concentration of the synthesized complexes, the nutrient broth was then inoculated into the agar plate to assay for the bactericidal effect. It was inoculated for twenty hours at $37^{\circ} \mathrm{C}$. It was shown that the lowest concentration of the ligands inhibited the growth on the plate immediately after incubation (Alade and Irobi, 1993).

\subsection{Stoichiometry and stability constant of complexes}

\subsubsection{Preparation of the ligands solution}

A modified procedure as reported in the literature was adopted (Tella and Obaleye, 2013). Fresh stock solution of Isonicotinic Acid Hydrazide and Pyrazine-2-carboxamide were prepared. A known certain weight of the ligands: Isonicotinic Acid Hydrazide $(0.14 \mathrm{~g} / \mathrm{L}$,$) and Pyrazine-2-carboxamide (0.12 \mathrm{~g} / \mathrm{L}$ in) were determined by dissolving them in their appropriate solvents $(20 \mathrm{ml}$ of ethanol and $20 \mathrm{ml}$ of mixed acetone-methanol) respectively. 


\subsubsection{Preparation of metals solution}

Solution of $0.05 \mathrm{M}$ of $\mathrm{Zn}(\mathrm{II}), \mathrm{Cu}(\mathrm{II}), \mathrm{Fe}(\mathrm{II}), \mathrm{Ni}(\mathrm{II}), \mathrm{Co}(\mathrm{II})$ and $\mathrm{Mn}(\mathrm{II})$ metals ( 0.07g/L, $0.06 \mathrm{~g} / \mathrm{L}, 0.06 \mathrm{~g} / \mathrm{L}, 0.06 \mathrm{~g} / \mathrm{L}, 0.06$ $\mathrm{g} / \mathrm{L}$ and $2.75 \mathrm{~g} / \mathrm{L}$ ) respectively were prepared by dissolving them in their suitable solvents. Distilled water was the only solvent used in dissolving all the metal ions (Tella and Obaleye, 2010).

\subsubsection{Determination of the absorbance of the metals - ligands solution}

Different solutions were prepared by adding different volumes of $0.05 \mathrm{M}$ of each solution of the metals and the ligands. The ionic strength was maintained using $0.1 \mathrm{M} \mathrm{KNO}_{3}$ at $\mathrm{pH}$ 7.4. The absorbance was determined using ultraviolet spectroscopy (Ogunniran et al., 2008).

\subsubsection{Stoichiometry determination}

Solution of $0.05 \mathrm{M}$ of the ligands and the metals were prepared. Different mixtures of the metal ions (Y ml) and (30-Y) $\mathrm{ml}$ of the ligands were top up to $30 \mathrm{ml}$ of a volumetric flask. Absorbance was determined using Ultraviolet spectroscopy following Job method of continuous variation (Ogunniran et al., 2012; Willey et al., 2008).

A graph of absorbance against concentration of metal ion divide by concentration of the metal ions and concentration of the ligands were plotted. 


\section{RESULTS AND DISCUSSION}

\subsection{Chemistry of the compounds}

The results of physicochemical data are as presented in Table 1. The melting points of the complexes were found to be higher than that of their parent ligands. This indicates the formation of the complexes (Fig. 1). The magnetic moments of the synthesized complexes are in the range of 0.68 B.M - 3.58 B.M. A magnetic moment of 0.68 B.M. was observed for Cd(II) complex which indicates that the complex is essentially diamagnetic. Nickel and cobalt complexes showed magnetic moment values of 3.47 B.M. and 2.29 B.M. respectively, suggesting octahedral geometry (Ogunniran et al., 2012).

The metal drug complexes were synthesized by refluxing method. The incorporation of the metals into the ligands spheres resulted in the formation of the complexes (Sousa et al., 2012). The compounds were characterized using Infrared spectroscopy and elemental analysis. The conductivity measurements were determined in methanol for the metal complexes with result indicating they are strong electrolytes. The elemental analysis of the complexes suggest that the compounds are pure and in good agreement with the molecular formula (Willey et al., 2008). 


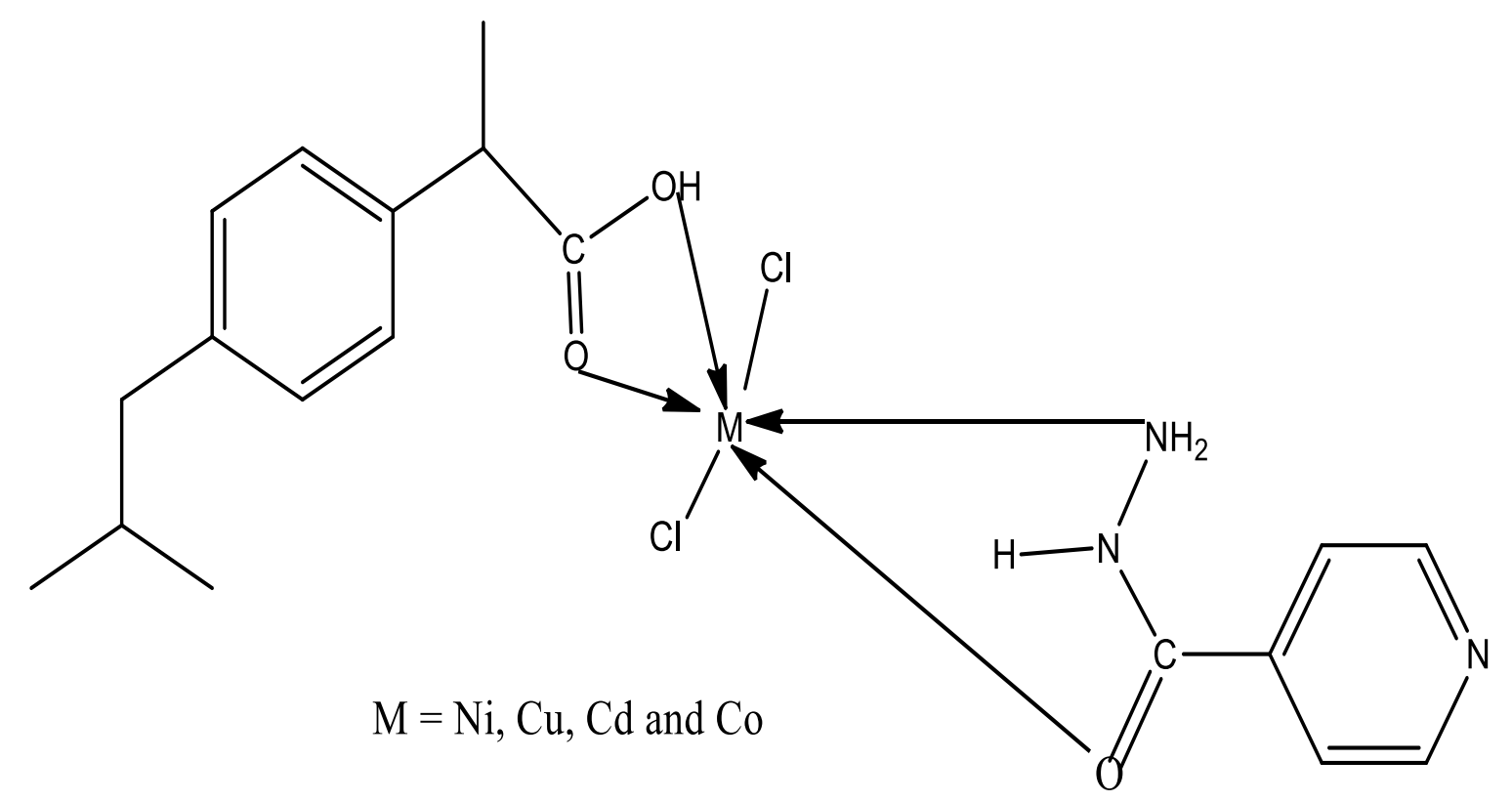

Figure 2: Proposed Structure of the complexes 
Table 1: Physiochemical data of the ligands and their complexes

\begin{tabular}{|c|c|c|c|c|c|c|c|}
\hline \multirow{2}{*}{ Ligands/Complexes } & \multirow{2}{*}{$\begin{array}{c}\text { Melting } \\
\text { Point (oC) }\end{array}$} & \multicolumn{4}{|c|}{ Found(Calculated $)_{0} / \mathrm{o}$} & \multirow{2}{*}{$\begin{array}{l}\text { Conductivity } \\
\Omega-1 \mathrm{Cm} 2 \mathrm{Mol}-1\end{array}$} & \multirow{2}{*}{$\begin{array}{c}\text { Magnetic } \\
\text { Susceptibility } \\
\text { (B.M) }\end{array}$} \\
\hline & & $\mathbf{C}$ & $\mathbf{H}$ & $\mathbf{N}$ & $\mathbf{M}$ & & \\
\hline Isoniazid [ISO] & $170-171$ & - & - & - & - & - & - \\
\hline Ibuprofen [IBR] & $75-77$ & - & - & -- & - & - & - \\
\hline$\left[\mathrm{Ni}(\mathrm{ISO})(\mathrm{IBR}) \mathrm{Cl}_{2}\right]$ & $195-196$ & $\begin{array}{c}48.11 / \\
48.23\end{array}$ & $\begin{array}{c}5.63 / \\
5.29\end{array}$ & $\begin{array}{l}8.21 / \\
8.88\end{array}$ & $\begin{array}{l}12.39 / \\
12.42\end{array}$ & 2.5 & 3.47 \\
\hline$\left[\mathrm{Cu}(\mathrm{ISO})(\mathrm{IBR}) \mathrm{Cl}_{2}\right]$ & $186-188$ & $\begin{array}{c}47.77 / \\
47.74 \\
\end{array}$ & $\begin{array}{l}5.57 / \\
5.24 \\
\end{array}$ & $\begin{array}{l}8.61 / \\
8.79 \\
\end{array}$ & $\begin{array}{c}13.29 / \\
13.31 \\
\end{array}$ & 3.1 & 3.58 \\
\hline [Cd(ISO)(IBR) $\left.\mathrm{Cl}_{2}\right]$ & 198-199 & $\begin{array}{c}42.95 / \\
43.31 \\
\end{array}$ & $\begin{array}{l}4.39 / \\
4.75 \\
\end{array}$ & $\begin{array}{l}7.43 / \\
7.98 \\
\end{array}$ & $\begin{array}{l}21.32 / \\
21.29\end{array}$ & 6.0 & 0.68 \\
\hline$\left[\mathrm{Co}(\mathrm{ISO})(\mathrm{IBR}) \mathrm{Cl}_{2}\right]$ & $189-191$ & $\begin{array}{c}48.17 / \\
48.21 \\
\end{array}$ & $\begin{array}{l}5.31 / \\
5.29 \\
\end{array}$ & $\begin{array}{l}8.81 / \\
8.88 \\
\end{array}$ & $\begin{array}{l}12.34 / \\
12.46 \\
\end{array}$ & 4.3 & 2.29 \\
\hline
\end{tabular}


Table 2: Infrared spectra of the ligands and their complexes

\begin{tabular}{|c|c|c|c|c|c|c|}
\hline Ligands/Complexes & $\boldsymbol{v}(\mathbf{C}=\mathbf{O})$ & $\boldsymbol{v}(\mathbf{O}-\mathbf{H})$ & $\boldsymbol{v}(\mathbf{C}=\mathbf{N})$ & $\boldsymbol{v}(\mathbf{N}-\mathbf{H})$ & $\boldsymbol{v}(\mathbf{C}-\mathbf{N})$ & $\boldsymbol{v}(\mathbf{M}-\mathbf{N})$ \\
\hline Isoniazid (ISO) & 1705 & 2945 & - & - & 2849 & - \\
\hline Ibuprofen (IBR) & 1666 & - & 1552 & 3300 & 2816 & - \\
\hline$\left[\mathrm{Ni}(\mathrm{ISO})(\mathrm{IBR}) \mathrm{Cl}_{2}\right]$ & 1786 & 3145 & 1616 & 3319 & 2810 & 516 \\
\hline$\left[\mathrm{Cu}(\mathrm{ISO})(\mathrm{IBR}) \mathrm{Cl}_{2}\right]$ & 1735 & 3142 & 1610 & 3425 & 2814 & 519 \\
\hline$\left[\mathrm{Cd}(\mathrm{ISO})(\mathrm{IBR}) \mathrm{Cl}_{2}\right]$ & 1720 & - & 1610 & 3319 & 2817 & 508 \\
\hline$\left[\mathrm{Co}(\mathrm{ISO})(\mathrm{IBR}) \mathrm{Cl}_{2}\right]$ & 1715 & 3146 & 1614 & 3314 & 2811 & 512 \\
\hline
\end{tabular}




\subsection{Infrared absorption spectra}

The Infrared bands of the prepared complexes were assigned based on the literature values obtained for similar structural compounds of the ligands (Sousa et al 2012; Ogunniran et al., 2008). The infrared spectra of both the complexes and the ligand (Fig. 3) were compared to determine the sites of coordination that may be involved in the synthesis (Ogunniran et al., 2012). A broad band within the region $3200-3600 \mathrm{~cm}-1$ is observed which is due to asymmetric and symmetric $\mathrm{O}-\mathrm{H}$ stretching vibration. The parent ligands act as a bidentate. Isoniazid is coordinated to the metal via the oxygen of the carbonyl group and nitrogen of the amine group while in Ibuprofen, the metal is coordinated through the oxygen of the carbonyl group and hydroxyl group. The band due to $\mathrm{v}(\mathrm{C}=\mathrm{O})$ and $\mathrm{v}(\mathrm{N}-\mathrm{H})$ were shifted to higher frequency in all the complexes. The shift to higher frequency for $\mathrm{O}$ in $\mathrm{v}(\mathrm{O}-\mathrm{H})$ and $\mathrm{v}(\mathrm{C}=\mathrm{O})$ indicate strong frequency and weak M-O. While shift to higher frequency in all the complexes indicates $\mathrm{v}(\mathrm{N}-\mathrm{H})$. This suggest strong $\mathrm{v}(\mathrm{N}-\mathrm{H})$ and weak M$\mathrm{N}$. 


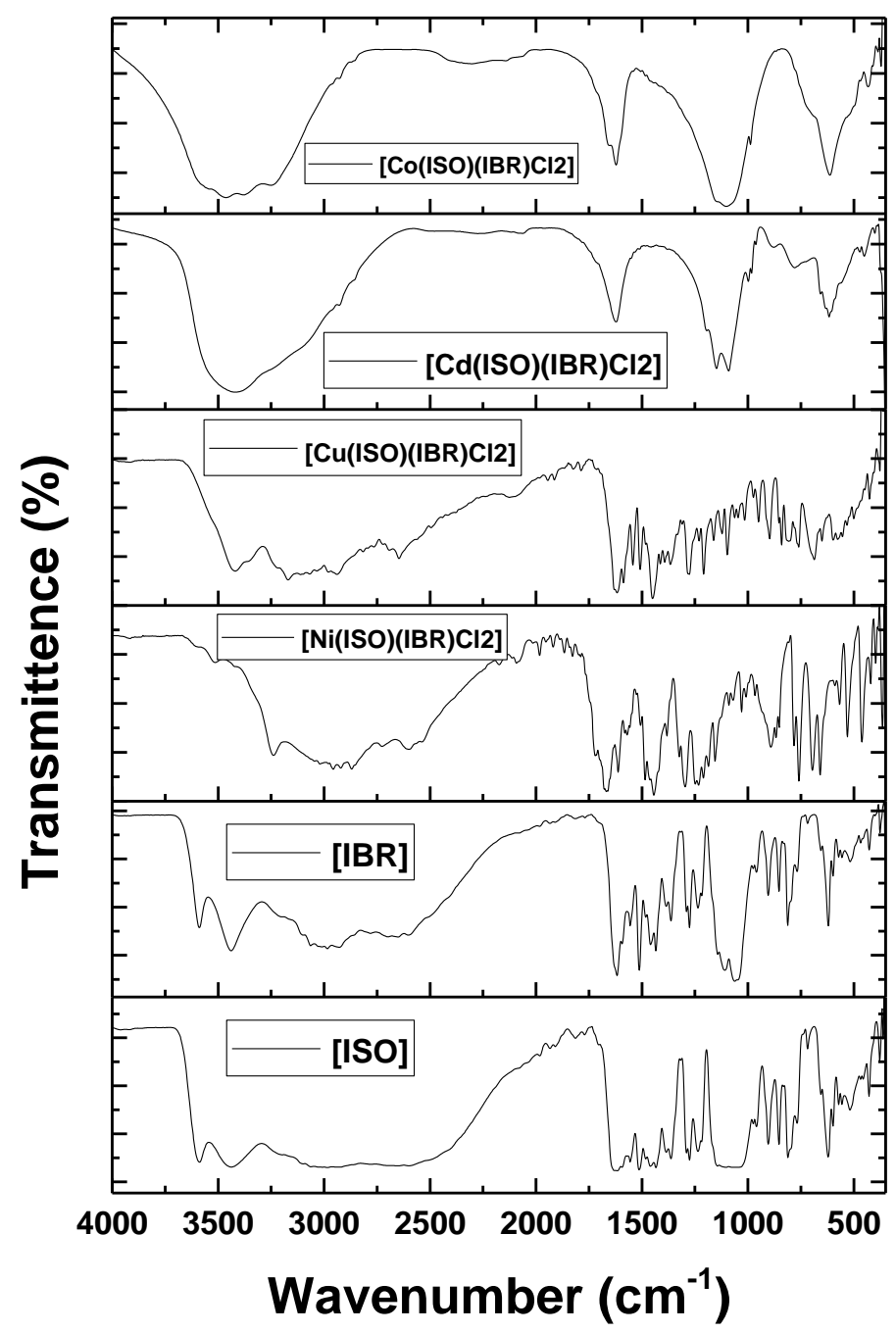

Figure 3: FT-IR of the synthesized complexes 
Table 3: Antibacterial activity of the ligands and their complexes

\begin{tabular}{|c|c|c|c|c|c|c|}
\hline \multirow{3}{*}{$\begin{array}{l}\text { Organisms } \\
\text { Ligands/Complexes }\end{array}$} & \multicolumn{2}{|c|}{ Escherichia Coli } & \multicolumn{2}{|c|}{ Staphylococcus aureus } & \multicolumn{2}{|c|}{ Pseudomonas aeruginosa } \\
\hline & \multicolumn{6}{|c|}{ Concentration $(\mu \mathrm{l} / \mathrm{ml})$} \\
\hline & 20 & 40 & 20 & 40 & 20 & 40 \\
\hline Isoniazid (ISO) & - & - & - & 11 & - & - \\
\hline Ibuprofen (IBR) & - & - & - & - & - & - \\
\hline$\left[\mathrm{Ni}(\mathrm{ISO})(\mathrm{IBR}) \mathrm{Cl}_{2}\right]$ & 11 & 14 & 8 & 12 & 8 & 13 \\
\hline$\left[\mathrm{Cu}(\mathrm{ISO})(\mathrm{IBR}) \mathrm{Cl}_{2}\right]$ & 4 & 16 & 5 & 24 & 14 & 19 \\
\hline [Cd(ISO)(IBR)Cl2] & 22 & 29 & 13 & 14 & 13 & 16 \\
\hline$\left[\mathrm{Co}(\mathrm{ISO})(\mathrm{IBR}) \mathrm{Cl}_{2}\right]$ & 9 & 12 & 11 & 11 & 17 & 18 \\
\hline
\end{tabular}


Table 4: Minimum Inhibitory Concentration of the ligands and their complexes

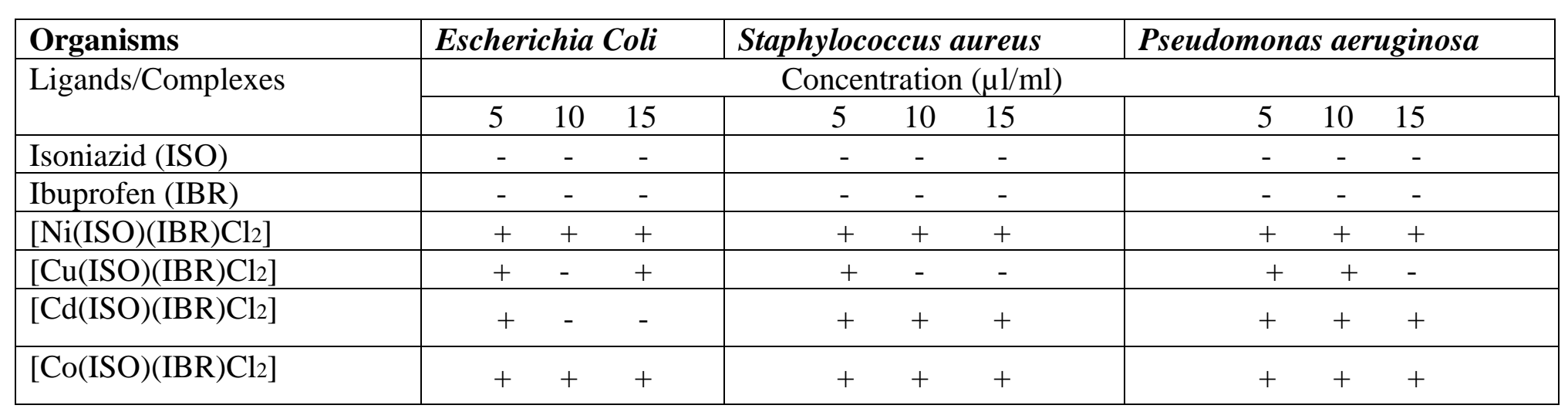


Table 5: Minimum Bactericidal Concentration of the ligands and their complexes

\begin{tabular}{|c|c|c|c|c|c|c|c|c|c|}
\hline Organisms & Esche & hia & & Stapl & ccus & & Pseuc & nas & ginosa \\
\hline Ligands/Complexes & & & & & cents & $(\mu 1 /$ & & & \\
\hline & 5 & 10 & 15 & 5 & 10 & 15 & 5 & 10 & 15 \\
\hline Isoniazid (ISO) & - & - & - & - & - & - & - & - & - \\
\hline Ibuprofen (IBR) & - & - & - & - & - & - & - & - & - \\
\hline$\left[\mathrm{Ni}(\mathrm{ISO})(\mathrm{IBR}) \mathrm{Cl}_{2}\right]$ & + & + & + & + & + & + & + & + & + \\
\hline$\left[\mathrm{Cu}(\mathrm{ISO})(\mathrm{IBR}) \mathrm{Cl}_{2}\right]$ & + & - & + & + & - & - & + & - & + \\
\hline$\left[\mathrm{Cd}(\mathrm{ISO})(\mathrm{IBR}) \mathrm{Cl}_{2}\right]$ & + & + & + & + & + & + & + & + & + \\
\hline$\left[\mathrm{Co}(\mathrm{ISO})(\mathrm{IBR}) \mathrm{Cl}_{2}\right]$ & + & + & + & + & + & + & + & + & + \\
\hline
\end{tabular}




\subsection{Antibacterial potentials}

It was also observed that the complexes compounds exhibit greater zone of inhibition acting agent bacterial species. This confirm that the coordination increases the capability of the complexes to cross a cell membrane (Chohan and Supuran, 2006). The complexes possess high susceptibility in all the selected organisms. This indicates a pharmacological potential in the development control of the organisms (Reddy et al., 2012). The antibacterial resistance against some antituberculosis drugs such as Isoniazid were known in different countries during in-vivo analysis of pathogen (Y1ldiz et al., 2012). The metal present in the complexes could help to enhance the effectiveness against the species used. The MIC and MBC of the ligands and their complexes were studied and compared with the parent free ligands as presented in Table 4 and 5 respectively. Based on the result obtained, it was observed that the complexes indicated MIC and MBC properties in all concentrations. The data obtained showed that all the complexes are more effective except $\mathrm{Cu}$ complex in MBC. In MIC, it was observed that $\mathrm{Ni}$ and Co complexes are more effective than $\mathrm{Cd}$ and $\mathrm{Cu}$ complexes. In general, it was indicated that the ligands are not effective against the organisms when compared with their complexes (Liebowitz et al., 2001). The order of MIC activity of the as-synthesized complexes against the studied strains follows the order: $\left[\mathrm{Ni}(\mathrm{ISO})(\mathrm{IBR}) \mathrm{Cl}_{2}\right]=\left[\mathrm{Co}(\mathrm{ISO})(\mathrm{IBR}) \mathrm{Cl}_{2}\right]>$ $\left[\mathrm{Cd}(\mathrm{ISO})(\mathrm{IBR}) \mathrm{Cl}_{2}\right]>\left[\mathrm{Cu}(\mathrm{ISO})(\mathrm{IBR}) \mathrm{Cl}_{2}\right]$.

Table 6: Stoichiometry Determination of Metals - Isonicotinic acid hydrazide in Solution

\begin{tabular}{|c|c|c|c|}
\hline Ligand & Metal : Ligand & $\lambda(\mathrm{nm})$ & $\mathbf{M}: \mathbf{L}$ \\
\hline \multirow{16}{*}{$\begin{array}{c}\text { Isonicotinic Acid } \\
\text { Hydrazide }\end{array}$} & \multirow{4}{*}{$\mathrm{Ni}(\mathrm{II}) \mathrm{ISO}$} & 365 & $1: 1$ \\
\hline & & 226 & $1: 1$ \\
\hline & & 218 & $1: 1$ \\
\hline & & 210 & $1: 1$ \\
\hline & \multirow{4}{*}{$\mathrm{Cu}(\mathrm{II}) \mathrm{ISO}$} & 245 & $1: 1$ \\
\hline & & 186 & $1: 1$ \\
\hline & & 167 & $1: 1$ \\
\hline & & 158 & $1: 1$ \\
\hline & \multirow{4}{*}{$\mathrm{Cd}(\mathrm{II}) \mathrm{ISO}$} & 357 & $1: 1$ \\
\hline & & 217 & $1: 1$ \\
\hline & & 209 & $1: 1$ \\
\hline & & 193 & $1: 1$ \\
\hline & \multirow{4}{*}{$\mathrm{Co}(\mathrm{II}) \mathrm{ISO}$} & 176 & $1: 1$ \\
\hline & & 148 & $1: 1$ \\
\hline & & 118 & $1: 1$ \\
\hline & & 112 & $1: 1$ \\
\hline
\end{tabular}


Table 7: Stoichiometry Determination of Metals - Ibuprofen in Solution

\begin{tabular}{|c|c|c|c|}
\hline Ligand & Metal : Ligand & $\lambda(\mathrm{nm})$ & $\mathbf{M}: \mathbf{L}$ \\
\hline \multirow{16}{*}{ Ibuprofen } & \multirow{4}{*}{$\mathrm{Ni}(\mathrm{II}) \mathrm{IBR}$} & 446 & $1: 1$ \\
\hline & & 211 & $1: 1$ \\
\hline & & 186 & $1: 1$ \\
\hline & & 153 & $1: 1$ \\
\hline & \multirow{4}{*}{$\mathrm{Cu}(\mathrm{II}) \mathrm{IBR}$} & 236 & $1: 1$ \\
\hline & & 211 & $1: 1$ \\
\hline & & 199 & $1: 1$ \\
\hline & & 171 & $1: 1$ \\
\hline & \multirow{4}{*}{$\mathrm{Cd}(\mathrm{II}) \mathrm{IBR}$} & 468 & $1: 1$ \\
\hline & & 308 & $1: 1$ \\
\hline & & 284 & $1: 1$ \\
\hline & & 200 & $1: 1$ \\
\hline & \multirow{4}{*}{$\mathrm{Co}(\mathrm{II}) \mathrm{IBR}$} & 431 & $1: 1$ \\
\hline & & 429 & $1: 1$ \\
\hline & & 377 & $1: 1$ \\
\hline & & 318 & $1: 1$ \\
\hline
\end{tabular}

Table 8: Stability Constant determination of Metals- Isonicotinic acid hydrazide in Solution

\begin{tabular}{|c|c|c|c|c|c|c|}
\hline Ligand & $M: L$ & $\begin{array}{l}\lambda \\
(\mathbf{n m})\end{array}$ & Lo & $\begin{array}{l}\text { Mo/A } \\
\text { X 10-4 }\end{array}$ & 1/Lo & $\begin{array}{l}\text { STABILITY } \\
\text { CONSTANT }\end{array}$ \\
\hline \multirow{4}{*}{$\begin{array}{l}\text { Isonicotinic } \\
\text { acid } \\
\text { hydrazide }\end{array}$} & \multirow[t]{4}{*}{$\mathrm{Ni}(\mathrm{II}) \mathrm{ISO}$} & 248 & 0.01 & 0.403 & 100 & 218 \\
\hline & & 231 & 0.02 & 0.433 & 50 & \\
\hline & & 234 & 0.03 & 0.427 & 33.3 & \\
\hline & & 282 & 0.05 & 0.355 & 20 & \\
\hline & \multirow[t]{4}{*}{$\mathrm{Cu}(\mathrm{II}) \mathrm{ISO}$} & 216 & 0.01 & 0.463 & 100 & 154 \\
\hline & & 354 & 0.02 & 0.282 & 50 & \\
\hline & & 277 & 0.03 & 0.361 & 33.3 & \\
\hline & & 213 & 0.05 & 0.469 & 20 & \\
\hline & \multirow[t]{4}{*}{$\mathrm{Cd}(\mathrm{II}) \mathrm{ISO}$} & 298 & 0.01 & 0.336 & 100 & 65 \\
\hline & & 314 & 0.02 & 0.318 & 50 & \\
\hline & & 323 & 0.03 & 0.309 & 33.3 & \\
\hline & & 487 & 0.05 & 0.205 & 20 & \\
\hline & \multirow[t]{4}{*}{$\mathrm{Co}(\mathrm{II}) \mathrm{ISO}$} & 141 & 0.01 & 0.709 & 100 & 114 \\
\hline & & 135 & 0.02 & 0.741 & 50 & \\
\hline & & 119 & 0.03 & 0.840 & 33.3 & \\
\hline & & 174 & 0.05 & 0.575 & 20 & \\
\hline
\end{tabular}

$\mathrm{M}_{\mathrm{o}}=0.01 \mathrm{M}$

Equation for determining stability constant of complexes:

$$
\mathrm{Mo} / \mathrm{A}=1 / \beta \varepsilon_{\mathrm{c}}[1 / \mathrm{Lo}]+1 / \varepsilon_{\mathrm{c}}
$$


Where $\quad \lambda(\mathrm{nm})=$ Absorbance $(\mathrm{A})$

$\mathrm{Lo}_{\mathrm{o}}=$ Concentration of the ligand

$M_{o}=$ Concentration of the metal ion

$\beta=\quad$ Stability Constant

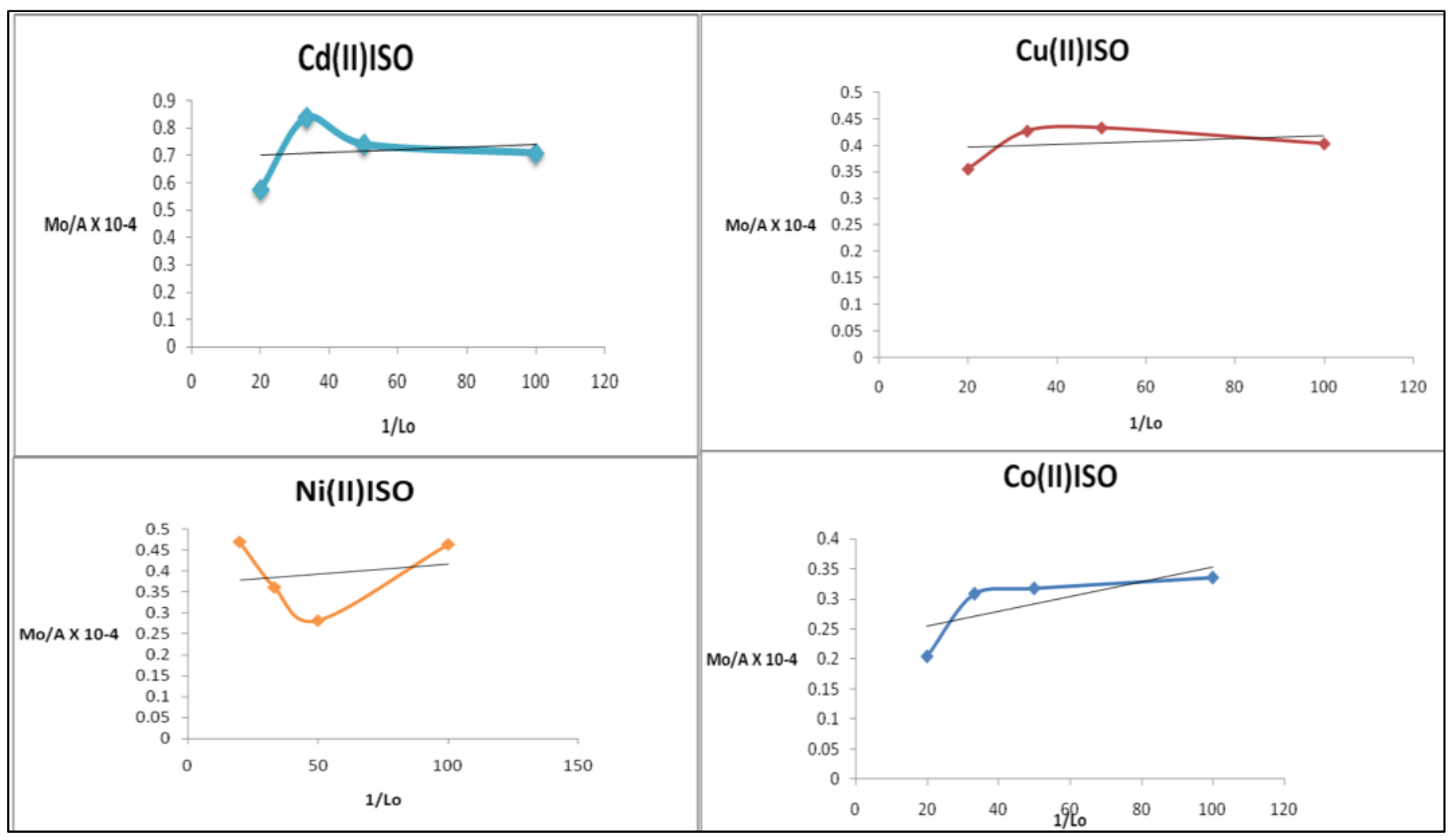

Figure 4: Graphical illustration of Stability Constant determination of Metals- Isonicotinic acid hydrazide in Solution

Table 9: Stability Constant Determination of Metal- Ibuprofen in solution

\begin{tabular}{|c|c|c|c|c|c|c|}
\hline Ligand & $M: L$ & $\begin{array}{l}\lambda \\
(\mathrm{nm})\end{array}$ & Lo & $\begin{array}{l}\text { Mo/A } \\
\text { X 10-4 }\end{array}$ & 1/Lo & $\begin{array}{l}\text { STABILITY } \\
\text { CONSTANT }\end{array}$ \\
\hline \multirow[t]{11}{*}{ Ibuprofen } & \multirow[t]{4}{*}{$\mathrm{Ni}$ (II)IBR } & 324 & 0.01 & 1.543 & 100 & 231 \\
\hline & & 300 & 0.02 & 1.667 & 50 & \\
\hline & & 216 & 0.03 & 2.315 & 33.3 & \\
\hline & & 412 & 0.05 & 1.214 & 20 & \\
\hline & \multirow[t]{4}{*}{$\mathrm{Cu}$ (II) IBR } & 186 & 0.01 & 2.688 & 100 & 127 \\
\hline & & 211 & 0.02 & 2.370 & 50 & \\
\hline & & 235 & 0.03 & 2.128 & 33.3 & \\
\hline & & 241 & 0.05 & 2.075 & 20 & \\
\hline & \multirow[t]{3}{*}{ Cd(II) IBR } & 146 & 0.01 & 3.425 & 100 & 81 \\
\hline & & 154 & 0.02 & 3.247 & 50 & \\
\hline & & 175 & 0.03 & 2.857 & 33.3 & \\
\hline
\end{tabular}




\begin{tabular}{|l|l|l|l|l|l|}
\hline & 219 & 0.05 & 2.283 & 20 & \\
\hline \multirow{3}{*}{ Co(II)IBR } & 193 & 0.01 & 2.591 & 100 & 118 \\
\cline { 2 - 6 } & 205 & 0.02 & 2.439 & 50 & \\
\cline { 2 - 6 } & 243 & 0.03 & 2.058 & 33.3 & \\
\cline { 2 - 6 } & 265 & 0.05 & 1.887 & 20 & \\
\hline
\end{tabular}

$\mathrm{M}_{\mathrm{o}}=0.01 \mathrm{M}$

Equation for determining stability constant of complexes:

$$
\mathrm{Mo} / \mathrm{A}=1 / \beta \varepsilon_{\mathrm{c}}[1 / \mathrm{Lo}]+1 / \varepsilon_{\mathrm{c}}
$$

Where $\quad \lambda(\mathrm{nm})=$ Absorbance $(\mathrm{A})$

$\mathrm{Lo}_{\mathrm{o}}$ Concentration of the ligand

$\mathrm{M}_{\mathrm{o}}=$ Concentration of the metal ion

$\beta=\quad$ Stability Constant

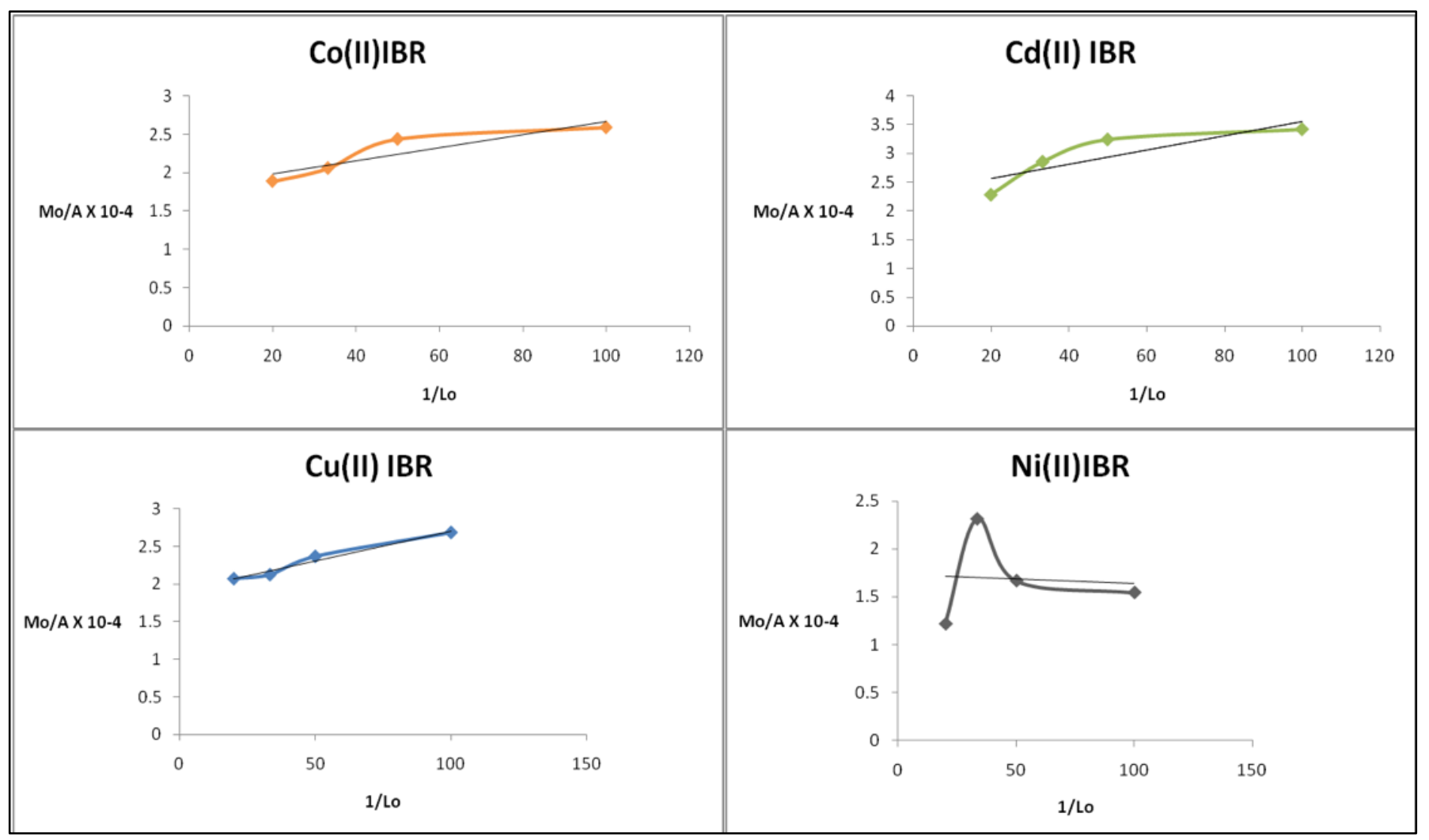

Figure 5: Graphical illustration of Stability Constant determination of Metals- Ibuprofen in Solution

From the result obtained for stability constants of the complexes as presented in Table 6-9, it was observed that the order of stability constant of the metal-ligand reaction follows this trend: $\mathrm{Ni}$ (II) $>\mathrm{Cu}$ (II) $>\mathrm{Co}(\mathrm{II})>\mathrm{Cd}(\mathrm{II})$. The stability constants were found to be inversely proportional to the ionic radius of the metals. Ni(II) complex is the most stable being the metal ion with the smallest ionic radii while $\mathrm{Cd}(\mathrm{II})$ complex is the least stable because the crystal field stabilization energy of Cadmium is equal to zero and the electronic configuration is d10. The order indicates that values increase with decreasing ionic radius of the metals. The order of the stability constant is in agreement with the trend of electronegativity and hence indicates that Irving-William rule is strictly obeyed (Irving and Williams, 1953). 


\section{CONCLUSION}

Isoniazid and Ibuprofen alongside their complexes showed good yield in stoichiometry ratio of 1:1 with refluxing method. The results of the physical and spectroscopic analysis of the complexes confirm that the ligands have chelating properties coordinating to the metal ion via the oxygen of the carbonyl and hydroxyl group in Ibuprofen, and nitrogen of amine and oxygen of carbonyl group in Isoniazid. The antibacterial screening investigation confirms that the complexes possess higher antimicrobial activities as compared to the free ligands. $\left[\mathrm{Ni}(\mathrm{ISO})(\mathrm{IBR}) \mathrm{Cl}_{2}\right]$ and $\left[\mathrm{Co}(\mathrm{ISO})(\mathrm{IBR}) \mathrm{Cl}_{2}\right]$ exhibited the highest antibacterial activities against the screened bacterial strains, followed by [Cd(ISO)(IBR)Cl2], while $\left[\mathrm{Cu}(\mathrm{ISO})(\mathrm{IBR}) \mathrm{Cl}_{2}\right]$ had the least activity, however, the activity was found higher than the free ligands. The results obtained in the study are of great significance towards further designing and developing metal (II) complexes towards combating bacterial resistance in the health sector. Incorporation of some metals into the bioactive ligands is a key metalloenzymes cofactor that can enhance greater inhibitory effectiveness against strains thus improving the development of a sensitive chemotherapy.

\section{Acknowledgement}

The authors acknowledge Industrial Chemistry Department University of Ilorin for their great support in providing for the reagents used during the research work.

\section{REFERENCES}

Adadey, S.A., Sarfo, J.K. (2016). Copper paracetamol complexes Promising lead antibacterial drug candidates. African Journal of Pure and Applied Chemistry. 10(5), 56-62.

Alade, P., Irobi, O.N. (1993). Antifungal activities of crude leaf extract of Acalypha wilkesiana. J. Ethnopharcol. 39, 171-174.

Amolegbe, S.A., Adewuyi, S., Akinremi, C.A., Lawal, A., Obaleye, J.A., Atayese, A.O. (2012). $\mathrm{Mn}(\mathrm{II}), \mathrm{Ni}(\mathrm{II})$, and $\mathrm{Cu}(\mathrm{II})$ Complexes of Artemisinin Derivatives: Synthesis, Characterization and Antimicrobial Activities. The pacific journal of science and Technology. 13(1), 424-429.

Arounaguiri S., Easwaramoorthy D., Ashokkumar A.(2000). Cobalt(III), nickel(II) and ruthenium(II) complexes of 1,10-phenanthroline family of ligands: DNA binding and photocleavage studies. Proc. Indian Acad. Sci. (Chem. Sci.). 112 (1), 1.
Bamigboye, M.O. Anibijuwon, I.I., Ajiboye, A.E. (2017). Chelation, Characterization And Antimicrobial Studies Of Mixed Nicotinamide Cloxacillin Metal Complexes. Nig. J. Pure and Appl. Sci. 30 (2).

Chaudhary, A., Phor, A., Singh, R. V. (2005). Potentially biodynamic tetraaza macrocycles and their manganese complexes: antiandrogen, antimicrobial and PDI studies," Bioinorganic Chemistry and Applications. 3(3-4),161-177.

Chohan, Z. H., Supuran, C.T. (2006). Metalloantibiotics: Synthesis,characterization and in-vitro antibacterialstudies on cobalt (II), copper (II), nickel (II) and zinc (II) complexes with Cloxacillin. Journal of Enzyme Inhibition and Medicinal Chemistry, 21(4), 441-448.

Collins, C.H., Lyne, P.M. and Grange, J.M. (1995). Microbiological methods (7thedn) Butterwort Heinemann Ltd. Britain. 175-190. 
Diana, E., Chierotti, M.R., Marchese, E.M.C., Croce, G., Milanesio, M., Stanghellini, P.L. (2012). Blue and red shift hydrogen bonds in crystalline cobaltocinium complexes. New J. Chem. 36,1099.

Diana, E., Chierotti, M.R., Marchese, E.M.C., Croce, G., Milanesio, M., Stanghellini, P.L. (2012). Blue and red shift hydrogen bonds in crystalline cobaltocinium complexes. New J. Chem. 36, 1099.

Irving, H. M. N. H., Williams, R. J. P. (1953). The stability of transition-metal complexes". J. Chem. Soc. 3192-3210. doi:10.1039/JR9530003192.

Liebowitz, L. D., Ashbee, H. R., Evans, E. G. V., Chong, Y., Mallatova, N., Zaidi, M., Gibbs, D. (2001). Global Antifungal Surveillance Group. Diagn. Microbiol, Infect. Dis. 4, 27.

Maria, K. R. B., Francis, R. N. A., Vasanthi, R. P., Paulraj, A. (2013). Mixed Ligand Complexes Of Nickel(II), Copper(II) And Zinc(II) With Nicotinanilide And Thiocyanate. International Journal of Life science and Pharma research, 3(2), 1 .

Mewis, R.E., Archibald, S.J. (2010). Biomedical applications of macrocyclic ligand complexes. Coord. Chem. Rev. 254,1686-1712.

Mukherjee, R. (2000). Coordination chemistry with pyrazole based chelating ligands: molecular structural aspects. Coord. Chem. Rev. 203,151-218.

Naglah, A. M., Al-Omar, M. A., El-Megharbel, S. M., Refat, M. S. (2015). Structural, conductometric and antimicrobial investigations of ibuprofen analgesic drug complexes with certain metal ions. International Journal of Pharmacology. 11 (7), 773785 .

Obaleye, J.A., Adediji, J.F., Adebayo, M.A. (2011). Synthesis and biological activities on metal complexes of 2, 5-diamino-1, 3, 4-thiadiazole derived from semicarbazide hydrochloride. Molecules 16 (7), 5861-5874.

Ogunniran, K.O., Ajani, O.O., Ehi-Eromosele,C.O., Obaleye, J.A., Adekoya, J.A. and Ajanaku, C.O. (2012). $\mathrm{Cu}(\mathrm{II})$ and $\mathrm{Fe}(\mathrm{III})$ complexes of
Sulphadoxine mixed with Pyrimethamine : Synthesis, Characterization, Antimicrobial andToxicology study. International Journal of Physical Sciences, 7(13), 1998-2005.

Ogunniran, K.O., Ajannaku, K.O., James, O.O., Ajani, O.O., Adekoya, J.A. and Nwionyi, O.C. (2008). Synthesis, Characterization, Antimicrobial activity and Toxicology study of some metal complexes of mixed antibiotics. African Journal of Pure and Applied Chemistry, 2(7), 69-74.

Poggi, M., Barroso, R., Costa-Filho, A. J., Barbosa de Barros, H., Pavan, F., Leite, F. C., Gambino, D., Torre, M. H., (2013). New Isoniazid Complexes, Promising Agents Against Mycobacterium tuberculosis. J. Mex. Chem. Soc. 57(3), 198-204.

Prasad, S., Agarwal, R.K. (2007). Cobalt(II) complexes of various thiosemicarbazones of 4aminoantipyrine: syntheses, spectral, thermal and antimicrobial studies," Transition Metal Chemistry, 32(2), 143-149.

Reddy, N.S., Rao, S.A., Chari. M.A., Kumar, R.V., Jyothy, V., Himabindu, V. (2012). Synthesis and bacterial activity of urea and thiourea derivative of anacardic acid mixture isolated from a natural product cashew nut Shell liquid. Intl. J. Org. Chem., 2, 267-275.

Sousa, E.H., Basso, L.A., Santos, D.S., Diógenes I.C., Longhinotti, E., Lopes LG, Moreira, S. (2012). Isoniazid metal complex reactivity and insights for a novel anti-tuberculosis drug design. J. Biol. Inorg. Chem.17(2), 275-83. doi: 10.1007/s00775-011-0848-x.

Tella, A.C., Obaleye, J.A. (2010). Metal-Chelator: Stability constants of Transition Metal complexes of Pyrimidine and Sulphonamide Drugs. Int. J. Chem. Sci. 8 (3), 1675-1683.

Tella, A.C., Obaleye, J.A. (2013). Solvent-free synthesis, $\mathrm{x}$-ray studies and in vitro inhibitory activities of copper(II) complexes of non-steroidal anti-inflammatory drugs._ Research on Chemical Intermediates. doi: 10.1007/s11164-013-10501052. 
Willey, J.M., Sherwood, L.M., Woolverton, C.J. (2008). Prescott, Harley and Klein's microbiology. McGraw-Hill,New York, NY, USA, 7th. ed.

Yıldiz, G., Tuba B., Fatma, K.O., Selda O., Mustafa, F.S., Deniz, S.D. (2012). Synthesis of some new urea and thiourea derivatives and evaluation of their antimicrobial activities. Turk. J. Chem., 36, 279-291. 